\title{
EL CONTROL DEL CUERPO Y LA SEXUALIDAD: ¿UN SIGNO DE SUMISIÓN O LIBERACIÓN?
}

The control of the body and sexuality: a sign of submission or liberation?

\author{
Ouafae Bouzekri
}

Universidad Mouly Ismail (Marruecos)

Fecha de recepción: 05/11/2018

Fecha de aceptación: 23/09/2019

RESUMEN: Este artículo tratará de analizar la tensión entre tradición y modernidad y cómo estas dos narrativas convergentes revelan un tenso debate sobre el cuerpo de la mujer en la región de MENA en general y en Marruecos en particular. Se describe cómo las mujeres tienen más oportunidades de educación y de disfrutar de derechos legales más fuertes y cómo algunas han adquirido liderazgo en diversos campos, incluso en aquellos dominados principalmente por hombres. Sin embargo, las mujeres siguen enfrentándose a la opresión, alimentada por una mezcla de cultura y religión que las degrada. Trataremos cómo en los últimos años las distintas formas de llevar el velo por parte de las mujeres musulmana ha estado en el epicentro de muchas disputas y controversias en el mundo occidental. Mientras que muchas mujeres musulmanas deciden usar el velo de acuerdo a su interpretación del Corán, o la de su imam, otras lo hacen como una seña de elección personal. Sin embargo, los no musulmanes a menudo ven el velo, particularmente los que cubren la mayor parte del cuerpo y/o el rostro, como una señal de opresión religiosa. Otros creen que el velo es una señal de radicalización, un movimiento hacia el islamismo.

PALABRAS CLAVE: velado, cuerpos de las mujeres, sexualidad, islam, liberación.

ABSTRACT: This article will endeavor to analyze the tension between tradition and modernity and how these two converging narratives reveal a tense debate about the body of women in the MENA in general and Morocco in particular. The article will explore how women have more opportunities for education and enjoy stronger legal rights and how some have even acquired leadership in different fields, even those fields that were mainly maledominated. Yet, women still face oppression fueled by a mix of culture and religion that debase them. We will deal with how in recent years the various forms of scarves worn by Muslim women have been at the center of many disputes and controversies throughout the Western world. While many Muslim women choose to wear the headscarves in accordance with their -- or their imam's -- interpretation of the Quran, others do so as a sign of personal choice. However, non-Muslims often see the veils (particularly those that cover most of the body and/or face) as a sign of religious oppression. Others believe the veils are a sign of radicalization, a move to Islamism.

KEYWORDS: veiling, women's bodies, sexuality, Islam, liberation.

\section{Introduction}

In this article, I will consider the tension between tradition and modernity and how both of these reflect a tense debate about the body in general and the female body in 
particular. In this digital world, there is no denying that women have challenged the roles traditionally assigned to them by invading the public sphere and guaranteeing successfully their involvement in the development of society at all levels. Women are doctors, engineers, ministers, governors, police officers, etc. In Morocco, for instance, women recently realized a victory by assuming the role of a public notary official locally known as 'Adoul', that has traditionally only been held by men. Yet, women still face a litany of discriminations and abuse fueled by a mix of culture and religion that regard women as the 'other' or as 'second class citizens'. Therefore, this article focuses on how in recent years the various forms of scarves worn by Muslim women have been at the centre of many disputes and controversies throughout the Western world. While many Muslim women choose to wear headscarves in accordance with their -- or their imam's -- interpretation of the Quran, others do so as a sign of liberation in the sense that being veiled facilitates for them access to public space without the supervision of their fathers or brothers or any male relative. Additionally, the wearing of the veil for many women lessens the jealousy of the husband as has been suggested in a study done by Hessini, reported by El Aji $(2019$, p.63) in her book 'Sexualité et Célibat au Maroc'. Non-Muslims on the other hand often see the veils (particularly the ones that cover most of the body and/or face) as a sign of religious oppression. Others believe the veils are a sign of radicalization, a move to Islamism - the most extreme interpretation of Islam. The veil is often considered an obstacle to integration. Much of the time, secular entities jump to the conclusion that Islamism or even Islam itself makes 'use of religion to perpetuate discriminatory laws and practices', in the words of Zainah Anwar, founder of the NGO Sisters in Islam. So, women in the $21^{\text {st }}$ century are still judged as moral, pure and labelled as 'good women' by their manner of dressing. Many questions arise, among which: how do moral perspectives and virtues indicate how bodies and specifically women's bodies need to be regulated and protected? How does the regulation of women's bodies impact society?

It will be hard to answer these questions without first raising the issue of the politics of the body which is considered to be 'the site in which social constructions are mapped onto human beings' (Brown \& Gershon, 2017). Indeed, subjugating the body to religious and/or governmental regulations is a way to guarantee that the body, the woman's body, behaves in socially and politically accepted manners. This is referred to as 'the cultivation of the body' which determines how one should behave in a society. This also explains why the body, and especially the woman's body, is politically inscribed and shaped by practices of containment and control. If we try to locate the body within western history, the first intellectual who popped into my mind is Karl Marx who claims that the body was marked with a person's economic status which in turn affects their experiences. The second is Foucault (1977) who argued that the body is a central site for analyzing the shape of power and added that the body has always been 'disciplined'. For him, 'discipline' produces subjugated and practised bodies, 'docile bodies' (Foucault, 1975, p. 138).

Many feminists have argued that the body is both socially shaped and colonized. Samora Machel, president of Mozambique in 1975 and an advocate of women's rights, warned against 'cultural imperialism' and feared what he called 'mechanical' emancipation of women within capitalist countries. Edward Said (1978) pointed out that women from the Middle-East were always portrayed as belly dancers, temptresses, and prostitutes or silenced in Harems. Their bodies, like the orient itself, were open to being conquered and dominated. This is well reflected in the representation of women by the orientalists in their painting who fantasize about Muslim woman and exhibit a sort of veiling which shows more than it covers, as in the sculpture of Antonio Corradini ( $18^{\text {th }}$ century) called 'Veiled woman'. Yet, we tend to forget that veiling existed before Islam. It was prevalent in the Mediterranean and 
Mesopotamian civilizations, where it was used as a sign to differentiate between free women (who veiled) and enslaved women (who did not).

\section{The genesis of veiling within Christianity and Islam}

According to Aboudrar (2016), among the three monotheistic religions, Christianity is the one that gives profound religious significance to veiling. Indeed, St Paul who is regarded as the embodiment of the scripture, explains in First Corinthians that women should be veiled as a sign of submission to men. The latter are their masters. Accordingly, men should not cover their heads because Jesus is their master. So, here, the veiling denotes a hierarchy that assigns a subordinate place to women and makes men superior:

In Corinthians 1, Chapter 11, Paul said:

a) But I would have you know, that the head of every man is Christ; and the head of the woman is the man, and the head of Christ is God.

b) Every man praying or prophesying, having his head covered, dishonoureth his head.

c) But every woman that prayeth or prophesieth with her head uncovered dishonoureth her head: for that is even all one as if she were shaven.

d) For if the woman is not covered, let her also be shorn: but if it is a shame for a woman to be shorn or shaven, let her be covered.

e) For a man indeed ought not to cover his head, for as much as he is the image and glory of God: but the woman is the glory of the man.

Paul's statement was adopted by many priests in churches. In the $3^{\text {rd }}$ century, Tertullian, a Latin priest, stated that a woman should be covered because 'le voile estson joug' and praised the Arab pagan women, who used to cover, three centuries before Islam. So, within Christianity, veiling, rejected by secularists, has become a common dress among nuns and does not cause any fuss. We should not forget either that veiling, as the anthropologist German Tillion asserts in his book 'Le harem et les cousins', was common among women in the Mediterranean region and denotes a class distinction in the sense that a free woman from the upper class cannot go out 'les cheveux en l'air' and always wore a hat so as not to be taken for a maid, a slave or a poor woman.

\section{Veiling within the Islamic tradition}

Within Islam, the argument for the hijab occurs with surah Al Nur:

Tell the believing men to lower their gaze and conceal their genitals. That is purer for them. Indeed, Allah is acquainted with what they do. And tell the believing women to lower their gaze and conceal their genitals and not expose their adornment except that which [necessarily] appears thereof and to wrap [a portion of] their headcovers over their chests/bosoms and not expose their adornment except to their husbands, their fathers, their husbands' fathers, their sons, their husbands' sons, their brothers, their brothers' sons, their sisters' sons, their women, that which their right hands possess, or those male attendants having no physical desire or children who are not yet aware of the private aspects of women. And let them not stamp their feet to make known what they conceal of their adornment. And turn to Allah in repentance, all of you, $\mathrm{O}$ believers that you might succeed (Quran, verses 30-31). 
Within this verse, the key words are ghadd al-bassar (lower your gaze) and hifth alfuruj (guard or cover the genitals). These are central to the code, and men are first mentioned as having to abide by these two premises. In other words, the Quran recommends men to control their gaze at women and to suppress their passion and forwardness when interacting with strange women. The divine message addresses both men and women. The verse specifies that women should cover their bosoms and not their heads. This is a reference to women who used to go out in the pre-Islamic period with a provocative 'décolleté'. Another prohibition concerns anklets. The admonition 'that they should not strike their feet' is a reference to the practice in which women wear anklets made of heavy metal (silver or gold). It is not the anklet per se that is erotic, but the jingling that evokes erotic passions. Other liberal scholars explain deeply the notion of the bosom. For Shahrour as it is mentioned by Fathi-Rizk (2011) in:

gayb' (bosom) etymologically means 'pocket', which refers to all the women's parts resembling pockets, of which the inside is hidden-like the underarm, under and between the breasts, the vagina and the anus, the exposure of which would represent a sin. However, the mouth, the ear, the nostrils are not pockets, in the sense that they're features of the face -not hidden ornaments-the visible signature of human identity. Following his definition of God's huddud (limits, boundaries) a minimum acceptable is to cover the aforementioned pockets, and the maximum limit would be the injunction of the prophet to leave visible only the face and hands. What is below and what is above these limits are sins-like the niqab that overpass the limit, or the revealing of the "pockets" that trespasses the borderline. The in-between depends on local customs and traditions. Thus, the Qur'an limits are part of the dynamics of the text, receptive to the social and historical context in which it operates (p. 24).

On the same line as Shahrour, okla (Fathi-Rizk, 2011) confirms this within the ayah that stipulates: 'they shall not reveal any parts of their bodies except what is necessary' ( $p$. 24). It gives the human the freedom to decide the definition of 'which is necessary' according to its time and space. Gamal El Banna mocks the interpretation of 'what is necessary' as indicating the face and the hands and judges it as far-fetched. Like the other scholars, he interprets it as women's freedom to decide what is right for them to wear according to the spirit of 'righteousness'. Therefore, the last part of the verse stresses the notion of modesty and the avoidance of being provocative (Fathi-Rizk, 2011). Within Islam, a woman's sexuality does not diminish her respectability. Islam, in fact, supports this combined image in womanhood. What Islamic morality forbids is the public flaunting of sexuality. Dressing and moving in a way that draws sexual attention to the body is 'tabarruj' (exhibitionist dress or behavior).

The other surah regulating women's code of dress is: 'O prophet, tell your wives, your daughters, and the wives of the believers that they shall lengthen their garments. Thus, they will be recognized and avoid being insulted. God is forgiver, Most Merciful' (Quran, Surah 33 , verse 59).

It is addressed to the wives of the prophet. So the regulation applies to the time of the prophet and is by following the spirit of Islam. The word 'lengthen' implies that there is no indication of how long the garment should be, to the ankle, below the knee or above. God left it to the customs of different communities to define the length of the dress. Above all, it is righteousness and modesty that are the cornerstones to define what appropriate or not. 
The other ayah to argue about the code of dressing is surah 'Al Ahzab':

Believers, do not enter the houses of the prophet for a meal without waiting for the proper time unless you're given leave. But if you're invited, enter, and when you have eaten disperse. Do not engage in familiar talk, for this would annoy the Prophet, and he would be ashamed to bid you go, but of the true God is not ashamed. If you ask his wives for anything, speak to them from behind curtains. This is more chaste for your hearts and their hearts (Quran, Surah 33, verse 53).

The orthodox view relies on this ayah to assert the mandatory requirement for women to veil whereas the modernist interpretation (El Tibi, 2013; Lmrabet, 2017; Mernissi, 1987; Wadud, 1999) confirm that the hijab in the sense of veiling occurs only in this ayah to concern exclusively the wives of the prophet, and not to all Muslim women. More than that, the only person to take as a model and to emulate is the prophet. Besides, it is clearly stated in the Koran that the wives of the prophet are not like the other women. If the women were to behave like the wives of the prophet, they should never remarry after the death of their husbands: 'You must not speak ill of God's apostle, nor shall you ever wed his wives after him; this should be grave offence in the sight of God' (Surah 33, verse 54) In Fatih-Rizk (2011, p. 26). According to Mernissi (1987), we have to take into account 'Assbab Anouzoul' and the circumstances of the revelation. For her, the hijab the Koran mentions is meant to indicate a certain "drawn between two men" alluding in this context to an incident in which guests lingered during their visit to the prophet and his new wife and the prophet out of courtesy couldn't ask his guests to leave. Hijab in this context was meant to provide privacy for the prophet and his family and to conceal women behind veils. As Mernissi said: "Allah's concerns in this verse are about tact. He wanted to intimate to the companions' certain niceties that they seemed to lack" (p. 92). For Mernissi "Reducing or assimilating this concept to a scrap of cloth that men have imposed on to veil them when they go into the streets is truly to impoverish this term, not to say to drain it of its meaning, especially when one knows that the hijab, according to the Koranic verse and Al-Tabari's explanation, 'descended from heaven to separate the space between men."' (p. 95). I'll add that veiling is more a tradition than a religious act. Islam focuses on good acts, on 'taqwa', on piety, good manners; and that 'taqwa' cannot be measured with the length of a dress or a piece of cloth. Islam, like any other monotheistic religion, recommends its believers to be modest and to dress decently. Veiling is not a religious object and to try to give it this status is to adhere to a very narrow and conservative interpretation. The variety of veiling that exists nowadays like la burqa, tchador, niqab or other forms have no Islamic foundations. They are simply cultural forms of dressing prevalent in certain geographical areas. For instance, the 'tchador' is a traditional dress of archaic Persian custom and is foreign to Islam. The 'burqa' is a recent dress common among the Pashtun tribes in Afghanistan. And the 'niqab' is a local dress within Golf countries. To adopt these forms of dressing to show one's piety is an exaggeration and goes against the prescription of Islam, a religion that encourages moderation 'al-Wassatiyah' and practicality/easiness 'Al-Yusr'.

\section{Opting for the veil: A liberation or oppression}

The increasing number of veiled women in the Middle East and North Africa reflects a shift that happens with a shift from conservative to liberal dress and back again. This shift has been framed under different dichotomies: 'Islam' verses 'the west', or 'the traditional' verses 'the modern', or 'the religious' 'verses' 'the secular', or the backward' verses the 
progressive'. To talk about one of them or criticize it becomes very complex because the dichotomy suggests that you adhere to one ideology or the other. Yet we should discuss veiling without having to choose between either side.

The association of veiling with oppression goes back to the reformer Qassim Amin in a book called Thrir Al-Mar'a (The liberation of women), who explicitly associated the oppression of women as residing in her invisibility, incarnated in the wearing of the veil. In Morocco, when the country obtained its independence from France after the French Protectorate, which lasted from 1912 to 1956, King Mohamed V unveiled his eldest daughter Lalla Aicha in public and called for the necessity of emancipating women to develop Moroccan society. This event marked the consolidation of feminism in Morocco. Since then, unveiling and working outside the home have been associated with nation-building. And, women were at the forefront of stardom and modernity. Women competed with men in jobs and professions. They enjoyed equal opportunities. Indeed, the former leader of the Socialist Union of Popular Forces (USFP) Abdullah Ibrahim argued in 1973 that women's fight for emancipation was not against men but was a common struggle carried out by both sexes, as there are no differences between males and females. In my childhood, my mother and my aunts gave up veiling as it had come to be considered backwards. I remember my aunt telling me that she used to veil only to go to the mosque or attend funerals. Then came the rising association of piety with the wearing of the veil for women and the growing of beards for men as a program of Islamization of society incarnated in the Muslim Brotherhood movement. Women affiliated with this movement adopted the veil as a new public appearance and demeanour that reaffirms their Islamic identity and morality and at the same time rejects western modernism. By dressing in this way, these activist Muslim women translated their Islamic ideals, their notion of egalitarianism, their belonging to the Muslim community. By veiling, their Muslim identity becomes visible and at the same time, they enhance their privacy and their quest for justice and not equality. For them, equality is a westernized concept. Equality has already been established by Islam. What they're demanding is justice.

Unfortunately, what we are witnessing nowadays in our society is the spread of the notion of the "purity culture" that objectifies women's bodies and controls them because they are viewed as a tempter for boys and men. Eltahawy (2016) states that the 'purity culture' is used to describe in the United States "the religious right's rhetoric that stresses virginity and modesty as the way for women to attain 'purity'... [it became] appropriate as a way to describe the pressures women in the middle-East and North Africa are subjected to and it reminds us how much the global religious right-wing has in common. Lmarbet said in a conversation with Slimani (2017) that women live/exist with that sword of Damocles hanging over their heads. Anybody can say anything under the umbrella of religion. Once we want to justify a way of suppressing you, we bombard you with this famous statement: 'it is mentioned in the Koran'.... She continued and asserted that 'we live in a society where religion has been reinforced and where the woman is summoned to represent the Muslim identity. The body of the woman is a terrible burden. The visibility of women determines the degree of Islamization of society. The honour, the image, the transmission, the virtue, all lie on the shoulder of the women (p.115).

Nowadays, we've reduced our religion to 'halal' and 'haram' and women are the scapegoats. Mothers are held responsible for the purity of their daughters. And this is often used as a weapon by the husband to put pressure on his wife and make her as obedient as her daughter. Mothers are accountable to their husbands and the latter are accountable to society. 
Within this context, girls are constantly 'hammered' with how their bodies should be covered from a very early age and they grow up in the fear of that body. This phobia often creates psychological trauma that deeply affects women's and girls' lives. 'Wearing the hijab as a freedom of choice' is a lure because we participate in encouraging the invisibility of women and at the same time denying space and freedom to the women who choose to reject the hijab and the repression it represents. We have to open our eyes to the atrocities faced by Muslim women who don't keep their 'proper place'. Acid has been thrown on women's faces because they dared to withdraw their veil, women have been imprisoned and beaten because they refused to wear it. Not only that but with the advent of Wahhabism and Salafism across the Muslim world, the hijab is being enforced on girls as young as 5. As Lmrabet (2016) said: 'To veil young girls is in itself a contradiction, even in the most conservative interpretation of Islamic practice, which holds that young girls should follow a strict dress code. It's an aberration to see this phenomenon in our schools and our school books. Adopting the veil should be a free, individual, spiritual choice and should not be seen as a pillar of Islam'. She also maintains that we are 'still a long way from the humanist message of the Coran that puts the valuing of human beings (al-insan: man and woman) above all other considerations, that is to say above religion, ethnicity, race or sex.'

\section{Conclusions}

It's time that we believe that young girls and women-especially young womendeserve a model of morality that is based on ethics, and not on their bodies. It's high time to do away with outdated -and dangerous -notions of veiling or non-veiling as if our bodies were reduced to a package of meat, or to the covering of our head, or how long or how short our skirt is. If young women's only ethical worth is based on whether they're chaste or cover themselves, then we're ensuring that they will continue to define themselves by their sexuality and not by what they are and the role they should play as full citizens who participate fully in the development of their society.

\section{References}

Aboudrar, B.N. (2016). Le Voile est Chrétien. Din Wa Dunia, 3.

Brown, N., \& Gershon, S.A. (2017). Body politics. Politics, Groups, and Identities, 5(1), 1-3. doi: $10.1080 / 21565503.2016 .1276022$

El Aji, S. (2019). Sexualité et célibat au Maroc. Pratiques et verbalisation. Maroc: La Croisée des Chemins.

Eltahawy, M. (2015). Headscarves and Hymens. Why the Middle East needs a Revolution. United States: W\&N.

El Tibi, Z. (2013). L'islam et la Femme. Rappel pour en finir avec les exagérations et les clichés. París, Francia: Desclée De Brouwer.

Fathi-Rizk, N. (2011). Women in the Middle East and North Africa. Agents of change. In F. Sadiqi \& M. Ennaji (Ed.), The veil. Religious and historical foundations and the modern political discourse (pp. 15-35). London: Routledge. https://doi.org/10.4324/9780203851579 
Fath-Rizk, N. (2011). "The Veil: Religious and Historical foundations and the Modern Political Discourse". In F. Sadiqi, y M. Ennaji (Eds). Women in the Middle East and North Africa: Agents of Change. New York: Routledge.

Foucault, M. (1975). Discipline and Punish. The Birth of the Prison. Washington, EEUU: Book World.

Foucault, M. (1977). Power/Knowledge. In C. Gordon. (Ed.), The Eye of Power (pp. 55-62). New York, EEUU: Pantheon.

Lamrabet, A. (2016). Women in the Qur'an: an Emancipatory Reading. United Kingdom: Kube Publishing LTD.

Mernissi, F. (1987). Beyond the veil: Male-Female Dynamics in Modern Muslim Society. USA: Indiana University Press.

Mernissi, F. (1987). Le Harem Politique. Le Prophète et les Femmes. Paris: Albin Michel.

Slimani, L. (2017). Sexe et Mensonge. La Vie Sexuelle au Maroc. Paris, France: Les Arènes.

Wadud, A. (1999). Qur'an and Women. Rereading the Sacred Text from a Woman's Perspective. New York, EEUU: Oxford University Press. 